\title{
Público: a audiência performática em caixas de comentários no YouTube
}

\section{Public: performative audience in comment boxes on YouTube}

Paula Coruja ${ }^{1}$ 


\section{Resumo}

O presente artigo é resultado de parte de uma pesquisa de mestrado, que lança uma mirada para a audiência de canais no YouTube. Aqui, entretanto, expandimos essa reflexão para propor a noção de público ao nos referirmos a estes comentaristas de vídeos, o que se justifica pela dimensão performática que assumem ao marcarem posição, muitas vezes acionada por supertemas. Através da análise dos comentários em vídeos de uma playlist, conseguimos mapear alguns tipos de performances e seus fluxos, que estão apresentados no texto.

\section{Palavras-chaves}

Público, performance, YouTube, audiências.

\section{Abstract}

This paper presents part of a master's research, investigating the audience of channels on YouTube. Here, however, we expand the reflection to propose the notion of publics when referring to these video commentators, movement justified by the performative dimension they assume when marking position, often triggered by "super-themes". By analyzing the comments on a playlist's videos, it was possible to highlight types of performances and their flows, which are presented in the text.

\section{Keywords}

Public, performance, YouTube, audiences. 
Para entender quem são os sujeitos que pelas suas ações reconfiguram práticas e modos de agir, uma reflexão sobre as audiências (no plural) se faz necessária. Mais do que supor uma massa heterogênea de receptores, é necessário entender a conjuntura cultural (ou cibercultural) para podermos, com mais propriedade, aproximarmo-nos desses sujeitos. Assim, quem são essas pessoas que ocupam caixas de comentários no YouTube?

Esse artigo é resultado das reflexões acerca de como a audiência de canais de YouTube se expressa através de comentários nas caixas de comentários de vídeos postados na plataforma. A pesquisa maior, com os resultados completos, a que este artigo se filia, pode ser acessada em repositórios digitais (CORUJA, 2017). Aqui, entretanto, expandimos essa reflexão das audiências para propor a noção de público ao nos referirmos a estes comentaristas de vídeos, o que se justifica pela dimensão performática que assumem ao marcarem posição, muitas vezes acionada por supertemas (JENSEN, 1997).

Dessa forma, para deixar claro o percurso, o artigo está dividido em três partes: primeiro, uma reflexão sobre o contexto de possibilidades em que se inserem esses sujeitos a partir da convergência; em seguida, uma reflexão sobre como o conceito de audiência vem sendo trabalhado nos estudos de comunicação, principalmente através do pensamento de Orozco, que traz uma imensa contribuição aos estudos de recepção e consumo midiático, passando pela mirada dos estudos ciberculturais. Por último, apresentamos como a noção de público é importante para entender essa particularidade dos comentaristas de vídeos no YouTube, principalmente pela dimensão performática ao compartilhar seus pensamentos, seguido do resultado do mapeamento dessas performances a partir de uma playlist, Girl/Boy Power², de uma notória youtuber, Júlia Tolezano, a Jout Jout ${ }^{3}$, analisada durante a pesquisa referida anteriormente. 
Ao apresentar esse percurso teórico-metodológico, esperamos contribuir com os estudos em comunicação voltados ao consumo midiático e de performances em redes sociais na internet. Da mesma forma, esperamos poder expandir o diálogo sobre o tema. Antes de discutir o conceito de audiência, é imprescindível compreender o atual contexto em que esses sujeitos estão inseridos a partir da noção de convergência. Estamos em uma época em que mais do que a convergência dos meios, temos convergência de conteúdos e um fluxo maior de sujeitos em processos de comunicação em rede, o que indica, preponderantemente, uma mudança cultural.

É justamente a partir daí que Jenkins (2009) aponta que, mais do que questões tecnológicas, convergência diz respeito à cultura. Passa, então, a ser entendida dentro de um contexto de fluxo: múltiplos conteúdos - e formas de interação em múltiplas plataformas. Para o autor, a convergência é uma "transformação cultural", pois convida a sair em busca de novas informações e conexões, com uma apropriação que hoje é mais visível, uma vez que deixa uma série de rastros. A convergência muda a forma de produzir e consumir informação, transformando essa em um processo muito mais imbricado no cotidiano, principalmente para aqueles que usam as redes sociais digitais não somente como forma de expressão, mas como uma forma de luta pelo direito de participar - e ser protagonista - da cultura.

Como mencionado anteriormente, a cultura participativa (JENKINS, 2009) pode ser considerada um fenômeno em si, galgado na criação e compartilhamento de conteúdos entre os consumidores de mídia. Nossa divergência com relação ao que aponta Jenkins, que presumia uma passividade da audiência em relação aos meios de comunicação, é de que os espectadores nunca foram totalmente passivos às mensagens dos meios, e agora, conjuntura na qual a internet e as redes sociais proporcionam um maior espaço de expressão e visibilidade das interações e tensionamentos, esses sujeitos encontram formas mais efetivas de articulação para disputar espaços e transformar a própria cultura. Desse modo, as manifestações desses sujeitos ficam registradas e explícitas nos ambientes de interação propiciados pelos sites de redes sociais, como o YouTube. 
Além disso, pensar na cultura participativa pode ser o ponto de partida para entender a contemporaneidade, mas não é um ponto final. Para Van Djick (2013, p. 4-5), partimos de uma cultura participativa para uma cultura da conectividade, em que a sociabilidade passa pela incorporação e o uso de plataformas digitais e o on-line se transmuta em uma nova camada para organização da vida. A autora também destaca que a construção de plataformas e as práticas sociais que se desenvolvem em (e para) cada uma delas são mutuamente constitutivas (VAN DJICK, 2013, p. 6). Dessa forma, as interações em sites de redes sociais como o YouTube não só fazem parte do cotidiano dos sujeitos e configuram a sociabilidade no contemporâneo, como são fundamentais para o desenvolvimento (e lucro) das empresas proprietárias dessas plataformas.

Contudo antes de tentar entender que audiência(s) é/são essa(s) que encontramos no canal estudado no YouTube, é preciso refletir sobre o próprio conceito de audiência para descobrir o que isso significa em um contexto em plena mutação das práticas comunicacionais, como experimentado na contemporaneidade.

\section{Audiência: de abstrata a interagente}

Recorro ao conceito de audiência desenvolvido por Orozco (1996), para quem os sujeitos são complexos e vão além de uma massa heterogênea acrítica. Orozco se dedica, desde a década de 1980, a pensar, teórica e empiricamente, sobre as audiências, e propõe a ideia de uma audiência mais genérica e ampla, capaz de ressignificar os produtos midiáticos. Quando desenvolve seu trabalho, Orozco parte da audiência da televisão e pensa na dimensão educativa da comunicação, a partir da perspectiva das mediações. Para Orozco (1998, p. 171), a televisão tem uma tripla dimensão: como meio, tecnologia e instituição social.

Por isso, o processo de comunicação deve ser pensado também de forma mais ampla, englobando não apenas processos de produção e emissão de mensagens, mas considerando o processo de recepção. Por isso, o autor refuta a ideia de uma passividade comum a todos os telespectadores, salientando que 
"ao encontro dos significados propostos pelas instituições, o receptor o enfrenta com todo seu repertório" (OROZCO, 1987, p. 64).

Uma das particularidades do discurso televisivo, e que se torna central para Orozco pensar a recepção, é sua polissemia que é "suscetível de ser percebida em muitos aspectos pelo público [...] tem a possibilidade de interpelar a mais audiências" (OROZCO, 1991, p. 112). Essa polissemia seria inclusive de meios, já que entende que leitores, ouvintes, espectadores e telespectadores são audiências que mudam seus modos de ser dependendo do meio a que se dedicam no momento. Nesse momento, o plural ao falar em "audiências" é essencial, já que para o autor a polissemia discursiva também atinge múltiplos grupos, heterogêneos ou não. Para o autor, o mister é "a mediação que se põe em jogo entre a significação preferencial da TV e audiências específicas" (OROZCO, 1991, p. 113) e que a maneira de ver TV é muito importante nessa negociação de significados com a audiência.

Essa concepção supõe três pontos: 1) que o encontro da audiência com a TV não se dá no vazio e que os espectadores não chegam com uma "mente em branco"; 2) que não existe uma só audiência televisiva, mas muitas audiências, ou uma audiência segmentada; 3) e que as mediações (a exemplo de como MartínBarbero as compreende) atuam diretamente na negociação e posterior produção de significados pelas audiências. E justamente por haver uma negociação e produção de significados, Orozco defende que a audiência não pode ser passiva, e que está mental e fisicamente ativa em sua interação com a programação televisiva (1991, p. 114). O autor salienta que "as audiências são ativas, mas, sobretudo, criativas" (OROZCO, 1991, p. 122) ao afirmar que a produção de sentido está também na interação social.

O autor reconhece que as audiências são sujeitos comunicantes (OROZCO, 1997a, p. 27), que são capazes de ler/escutar/ver criticamente, ou apenas ler/escutar/ver. Orozco identifica, a partir da virada do milênio, um contexto "caracterizado por um avassalamento audiovisual, eletrônico e digital sem precedentes" (OROZCO, 2001, p. 156). E, ao construir o que ele chama de uma "pedagogia da televidência", diz que as audiências se alteram para sujeitos- 
audiência. Se antes as audiências eram pensadas e definidas por critérios de segmentação social, como sexo, idade, etnia, escolaridade, religião, o processo de mass-mediação fez com que esses sentidos fossem expandidos, pensados agora por questões simbólicas e de gosto, privilegiando subjetividades.

O cenário que se configura a partir da cibercultura transforma o que é e como é ser audiência (OROZCO, 2008, p. 10), agora capaz experimentar a ressemantização das mensagens "de acordo com suas próprias intenções". Para Orozco (2009), o trânsito em múltiplas telas nos coloca em meio a um ecossistema comunicacional, o que faz que vivamos uma condição comunicacional, que consiste em uma recentralização do comunicativo como dimensão prioritária da contemporaneidade.

Para o autor (2010, p. 6), essa condição comunicacional é a principal responsável pelas mudanças nas possibilidades de ser audiência, que agora se abre para comunicantes, "já que a interatividade que permite as novas telas transcende a mera interação simbólica". Segundo Orozco (2012b, p. 67-68), encontramo-nos em uma realidade polimorfa e "cambiante" das audiências, na qual saímos de um período vertical de comunicação, para uma mudança cultural que introduz um período horizontal proporcionado pelo acesso à cultura digital, que proporciona uma interlocução mais proativa e criativa. Assim, inspirado no conceito de Jensen, Orozco (2012b, p. 68-71) afirma que a interatividade é a dimensão que modifica o estar como audiência e a transforma em usuário, e, até mesmo, fãs.

Orozco dialoga com Néstor García Canclini para traçar essa discussão, ao dizer que o consumo deve servir para pensar, produzir e situar-se como audiência mais propositiva, "em uma espiral ascendente de criatividade e empoderamento" (OROZCO, 2012b, p. 69). Dessa forma, coloca a ubiquidade e a hiperconectividade como as principais características das audiências contemporâneas. Assim, as audiências ativas hoje estão dadas, não precisam mais ser procuradas e reconhecidas, mas configuram o modo de ser, o que representa uma mudança qualitativa.

A convergência, neste cenário, é a responsável por uma "infidelidade" da audiência em relação às telas disponíveis e pelas possibilidades de consumo e ressignificação de uma multiplicidade maior de conteúdos (OROZCO, 2012c, p. 6). 
Comunicar passa a ser, também, entretenimento, especialmente para quem o autor identifica como "usuários-audiências jovens". Uma interação que se converte não só em modos de comunicar, informar, divertir-se, mas sobreviver (OROZCO, 2012a, p. 41). Por fim, o grande desafio que o autor ressalta é que as audiências se coloquem como interlocutoras (OROZCO, 2014, p. 22), principalmente dos conteúdos ficcionais diversos, já que novas possibilidades de popularização da produção desse conteúdo se abrem.

Diante do exposto, é possível reconhecer que não há apenas uma "audiência em trânsito" (2010a), mas um trânsito do próprio conceito e da maneira que o autor pensa a audiência. As transformações sociotécnicas das últimas duas décadas foram preponderantes nessa reflexão, que se mostra ainda sem respostas definitivas. As implicações dessas transformações, que, por mais que pareçam hegemônicas (ainda há populações inteiras sem acesso às plataformas digitais) clamam por respostas. O que falta avaliar é se as velhas respostas, pensadas de uma forma mais conjuntural, são suficientes para um contexto que se transforma quase que instantaneamente. Por isso, a discussão não se esgota na compreensão das audiências, mas abre caminho para verificar perspectivas outras que versam sobre o perfil dos sujeitos que estão interagindo no YouTube.

Outro conceito que pode ser associado à compreensão das audiências de canais do YouTube é o de "interagentes" (PRIMO, 2011). A exemplo do que faz Orozco, o termo é uma tentativa de fugir do reducionismo presente em definições como "usuário", "emissor" e "receptor". O conceito também remete a outra noção fundamental para compreensão das audiências: a de interação mútua. Na definição de Primo (2011, p. 57), "a interação mútua é aquela caracterizada por relações interdependentes e processos de negociação, em que cada interagente participa da construção inventiva e cooperada do relacionamento, afetando-se mutuamente". A partir dessa perspectiva, que se volta para as relações estabelecidas nos sites de rede social, essas ambiências também são criadas e subvertidas pelos interagentes como espaços que propiciam os relacionamentos. Tais interações deixam rastros registrados de fácil acesso. 
Os autores que pensam os sujeitos como interagentes analisam as interações (e/ou conversações), apesar de estarem sendo mediadas por dispositivos como computadores, tablets e smartphones, a partir de um espaço comum negociado, que, para o caso analisado na pesquisa, seriam as caixas de comentários dos vídeos de um canal no YouTube. E, como outros trabalhos destacam (STRANGELOVE, 2011; RECUERO, 2014; PRIMO, 2011), os sujeitos se apropriam desses espaços e ressignificam até mesmo suas funções básicas. Essa, segundo Lemos (2002), é uma das características essenciais da cibercultura, a apropriação, seja ela simbólica, com construção de sentido a partir do uso desviante das ferramentas, ou técnica, que só compreende o aprendizado de utilização da ferramenta. Como lembra Jensen (2010, p. 63), "novas tecnologias traçam novas linhas entre o possível e o impossível, mas elas não preveem o que exatamente se torna possível".

Portanto, mesmo que algumas funções sejam possibilitadas pela própria tecnologia, é só a partir dos usos e apropriações dos sujeitos que é possível falar de determinação. O mesmo acontece com o resultado do encontro (e interação) de diferentes sujeitos, com diferentes objetivos, que faz com que a conversação seja "portanto, menos uma determinação da ferramenta e mais uma prática de uso e construção de significado dos interagentes, sejam essas ferramentas construídas para isso ou não" (RECUERO, 2014, p. 39).

Dessa forma, essa perspectiva pensa os sujeitos como únicos, mas os vê, dentro das conversações, como interagentes de igual importância para o estabelecimento dessas relações; todos evidenciando sua agência a partir das práticas sociais dentro das redes sociais na internet. Entretanto não vemos, assim, uma grande diferença semântica no jeito de considerar esses sujeitos. Audiência(s) ou interagentes, mesmo que tenham sido concebidos em contextos diferentes e por bases teóricas distintas, mas não apartadas, estão todos inseridos em um cenário cultural maior, ambos reivindicando atividade. Ao pensarmos na relação desses sujeitos com determinados conteúdos, parece-nos importante tentar outra saída teórica que seja, ao mesmo tempo, abrangente, ao abarcar um grande grupo, mas específica, ao caracterizá-lo. Para isso, achamos importante resgatar o conceito 
de "público", que compreendemos definir melhor a relação entre as audiências de canais no YouTube, com as possibilidades dialógicas que já abordamos.

\section{De audiência a público: a performance nas caixas de comentários}

Livingstone (2005) explica que a noção de público costumava ser atrelada e constrita a determinados sujeitos, consumindo determinados produtos culturais em determinados espaços, como o teatro. Porém as relações entre audiências e públicos estão em transformação, e a visão dicotômica dos conceitos (audiência x público; privado x público; passivo x ativo; escondido x visível) não é mais capaz de explicar os fenômenos comunicacionais na contemporaneidade.

Para Babo (2013, p. 218), no momento em que se encontra na recepção um grupo de espectadores que comenta, engaja-se, emociona-se ou repudia um fato ou um produto midiático, tem-se mais do que "meras audiências". Ao contrário do que afirma Orozco, que vê a audiência como ampla e múltipla, no momento em que há essa dimensão do que ele chamou de "qualificação da audiência", Babo considera a formação de público. A autora portuguesa parte do entendimento de autores como Gabriel Tarde, Robert Park, John Dewey e Daniel Dayan, em uma análise que nos auxilia a pensar não só sobre os sujeitos investigados nesta pesquisa, mas a compreender um pouco melhor essas relações que se estabelecem em canais do YouTube, principalmente entre aqueles que demonstram um maior nível de engajamento com o conteúdo dos canais, comentando e interagindo com outros sujeitos a partir das caixas de comentários.

Ao dialogar com Esquenazi, Babo considera que público pode ser entendido como "coletivo concreto", ou seja, "'um grupo de pessoas que tem algo em comum'. Poderíamos dizer tratar-se de um grupo de particulares ligados por um desejo, interesse, convicção, gosto, experiência ou ação pública comum" (BABO, 2013, p. 219). Em seguida, a autora faz uma reflexão, a partir da obra de Gabriel Tarde, e acrescenta que há "uma dimensão contextual e política nos públicos", que se dá pela comunicação e o desenvolvimento da imprensa. Com os resultados das pesquisas desenvolvidas pela segunda geração de sociólogos do que se 
convencionou chamar de Escola de Chicago, novas noções importantes foram agregadas, como "o lugar do público é no seio do diálogo" (BABO, 2013, p. 219). Esses pensadores desenvolveram uma microssociologia, voltada para o cotidiano e o âmbito das interações, no início do século XX, mas que continuam contribuindo para os novos espaços públicos para onde olhamos com as redes sociais. De Dewey vem um entendimento que é central para a nossa reflexão:

[...] a comunicação é a condição prévia da participação e da formação dos públicos, pois na base destes estão as significações comuns partilhados que estabelecem laços sociais e podem converter uma ação conjunta numa comunidade de interesses [...] Não é dado antecipadamente, antes emerge através das interações entre as pessoas que se constituem como investigadores, que se mobilizam e participam (DEWEY, 2010, p. 278, grifo nosso).

Ou seja, essas significações comuns partilhadas, que emergem das interações entre os sujeitos e são capazes de mobilizar a participação, podem ser entendidas como o que Jensen (1997) chamou de "supertemas" da audiência. Jensen parte do fluxo televisivo para apontar conceitos específicos que estabelecem relações entre os temas propostos na esfera da produção e o cotidiano dos espectadores. Uma noção que é individual, mas que, ao identificarmos que muitos dos sujeitos partilham dos mesmos supertemas, podemos verificá-los como elementos de um coletivo.

Segundo Orozco (2000, p. 55), o supertema é uma categoria analítica central, já que é dentro dela que se "contextualiza o resultado empírico". É na identificação dos supertemas da audiência (ou dos públicos) que é possível perceber quais apropriações são feitas pelos sujeitos a partir de um mesmo produto midiático, como os vídeos de Jout Jout.

Uma das características apontadas sobre os públicos que nos parece fundamental para compreender os sujeitos que atuam no canal estudado é a noção de performance. Segundo Dayan (2006), é a performance que distingue público e audiência, e nessa há uma dimensão cênica da apresentação de si. Para Amaral, Soares e Polivanov (2018, p. 76), a performance pode ser uma 
categoria teórico-metodológica importante para compreender os sujeitos em sites de redes sociais, já que "formam a textura geral da experiência" dos sujeitos. Compreender o caminho teórico proposto pelos autores, desde as matrizes linguísticas que estão no cerne do uso do termo "performance" e as disciplinas que se debruçam sobre ela corroboram com o entendimento de que a performance é centro da distinção dos comentaristas de vídeo no YouTube (e, porque não, em outros sites de redes sociais) em relação a outros modos de ser audiência.

Um ponto importante, abordado por Dayan (2006), é que a noção de público é dependente da reflexividade. "Esta performance pode ser consensual ou polêmica, mas não pode ser invisível" (DAYAN, 2006, p. 30, grifo nosso). O autor aponta três principais características da performance dos públicos: 1) a dimensão cênica, já que não basta ver, mas também ser visto; 2) dimensão do sujeito coletivo, com reflexividade e deliberação; e 3) dimensão do compromisso, de defesa de convicções, escolhas e valores. Essas dimensões dialogam bem ao que propõe Bauman (1986), e que aparece no resgate teórico proposto por Amaral, Soares e Polivanov (2018), já que o autor enfatiza que a performance é sempre para um outro; ou com Turner (1982), que preconiza a performance como uma "transparência" capaz de mostrar aspectos de determinadas culturas.

Nesse sentido, a discussão não passa apenas por pensar o nível de agência dos sujeitos, ou o grau de engajamento, já que compreendemos que todo o ato de recepção e/ou consumo midiático envolve ação. Mas compreender todos aqueles que, de alguma forma, sentem-se mobilizados a também participar do canal, fazendo-se visíveis à youtuber e aos outros sujeitos da audiência. É necessário, para esse tipo de análise em canais no YouTube, compreender que os sujeitos engajados nas conversas não se conheceriam (não entrariam naquela relação) se não fossem movidos por um mesmo supertema. Fica claro que estão na caixa de comentários performando sua opinião em texto a partir de uma significação partilhada e deixam indícios, respostas, e opiniões sobre seus sentimentos, conceitos e preconceitos. 
Segundo Babo (2013), algumas práticas identificadas entre os sujeitos da pesquisa são centrais no que a autora define como público. Entre eles estão: 1) Partilha, como nos comentários em que os sujeitos dividem a própria história sobre o tema do vídeo; 2) Associação, quando os sujeitos usam a possibilidade de comentar para apoiar as opiniões uns dos outros; 3) Comprometimento, quando se comprometem a explicar pontos nos vídeos que não ficaram claros a outros sujeitos que haviam questionado isso anteriormente; 4) Diálogo, quando interpelam-se sobre um mesmo tema; 5) Juízo, quando são críticos aos vídeos e/ou a opiniões de outros sujeitos. Tudo isso nos é visível pelas diferentes performances do público investigado durante a pesquisa, que serão comentadas a seguir.

O tipo de conteúdo que observamos no YouTube produzido por youtubers e disponibilizado de forma seriada (com periodicidade fixa), confessional, ao falar sobres temas do seu cotidiano (já como uma performance de si), e que chama a audiência a dar sua opinião, fomenta um vínculo social (como a youtuber que foi analisada e o que ela chama de "família Jout Jout") e um espírito de comunidade, também suscita a formação de um público. Como já foi pontuado, o público é heterogêneo, marcado pela performance, pelo diálogo, pela expressão, reação.

Essas são apenas algumas das práticas que nos mobilizaram a refletir sobre os sujeitos que encontramos no canal JoutJout Prazer, uma audiência que é ampla, diversa, ativa e formada pelo conjunto de pessoas que acessa o canal e visualiza seus vídeos. Entretanto aqueles que de alguma forma dão-se a conhecer, performam sua opinião/sentimento em relação ao conteúdo do vídeo, formam o público do canal. São público porque lançam mão de práticas que os identificam como tal. Entendemos, assim, que um público não se forma de um indivíduo, mas de significados e práticas partilhadas, como vemos nas caixas de comentários em canais no YouTube.

Mais do que pensar uma diferenciação entre público e audiência, o que almejamos aqui é refletir e compreender como um está imbricado no outro, como é possível transitar, não só entre telas e posições de produção e recepção, mas em modos de recepção e apropriação. Para Hine (2004), o "ser" audiência, 
produtor e/ou usuário são posições móveis, que se dão a partir das práticas. Refletindo sobre o YouTube, Lange (2007) sugere que os papéis de espectadores e criadores estão constantemente em fluxo. Isso nos leva a pensar que mais do que novos conceitos e neologismos, é preciso uma maior consciência das posições que ocupamos conforme somos afetados por nossas práticas de consumo midiático.

\section{Algumas performances possíveis em caixas de comentários}

A partir da compreensão da mudança que acontece com a cultura da convergência (JENKINS, 2009) e a cultura da conectividade (VAN DJICK, 2013), a internet aqui é entendida como cultura e artefato (HINE, 2004). Dessa forma, a etnografia virtual serviu como referencial ao mesmo tempo teórico e metodológico importante durante a pesquisa, pois permitiu monitorar e analisar novas práticas sociais de forma qualitativa. As propriedades tecnológicas, assim, foram interpretadas como processos sociais. E a performance, na identificação dos modos como esse público se colocava em relação ao conteúdo, foi uma categoria importante para entender as relações ali expostas. Aqui, o canal JoutJout Prazer foi entendido como um espaço social próprio, onde uma audiência diversa (e dispersa) se encontra com expectativas e práticas próprias.

A etnografia virtual (HINE, 2004) estuda as práticas sociais na internet e o significado destas para os participantes. É uma forma de empreender um estudo detalhado das relações nos espaços virtuais, a partir da qual a internet deve ser compreendida como interface cotidiana da vida dos sujeitos e lugar de encontro que permite a formação de comunidades, grupos estáveis, além da emergência de novas formas de sociabilidade.

Hine (2016) também lembra que o etnógrafo da/na internet busca um profundo contato com essas práticas que investiga, para além do momento do engajamento dos sujeitos e da apreensão de textos (aqui entendendo "texto" a partir do sentido mais amplo, para além da linguagem escrita). Além disso, por esse olhar prolongado sobre as práticas, o etnógrafo busca significados que 
estão imbricados nas múltiplas relações sociais dos momentos de engajamento com esses textos.

Acredito que essa abordagem dê uma diretriz de como começar a compreender essas relações, a partir das interações visíveis nas caixas de comentários, para conseguir apreender os significados resultantes dessas práticas. Marques (2010), ao investigar espaços de conversação na internet, salienta que é preciso abordar o objeto de múltiplas formas para dar conta das interpenetrações com as experiências dos sujeitos. Se pensarmos que o ambiente que estudamos não só está na internet, mas se vale de conteúdos textuais e audiovisuais para estabelecer relações, demanda ainda mais atenção na combinação de estratégias metodológicas, como é o caso dos canais no YouTube.

Os processos metodológicos empreendidos durante a pesquisa podem ser vistos em detalhes em Coruja $(2017,2019)$. Para situar o/a leitor/a, apresentamos um resumo do que foi feito. A partir dos princípios da etnografia virtual, primeiro empreendemos uma pesquisa exploratória a partir da observação do canal e das interações em três vídeos. Para sistematizar os dados da primeira fase, os dados abertos das interações foram coletados e o conteúdo analisado com o auxílio do software NVivo, com os princípios da análise de conteúdo Bardin (2011), sendo possível apreender tipos de performance do público, e análise temática e análise de conteúdo qualitativa (OROZCO, 1996), para identificar temas e supertemas. Os procedimentos da pesquisa exploratória foram validados durante o exame de qualificação e a segunda parte da pesquisa prosseguiu valendo-se da etnografia virtual, como bússola metodológica, a partir dos procedimentos de observação do canal, análise dos vídeos e análise de conteúdo qualitativa comentários da playlist Girl/Boy Power (composta por 25 vídeos, com um total de 14.394 comentários).

Para este artigo, é importante pontuar que durante a pesquisa exploratória, o feminismo foi identificado como um supertema, discutido até mesmo nos vídeos em que o tema proposto pela youtuber não era esse. Nesse corpus exploratório de três vídeos e 2.987 comentários, foi possível observar que esse supertema perpassa 
os limites do vídeo em que é diretamente abordado. Os mesmos supertemas foram constatados posteriormente após o exame de qualificação quando a playlist Girl/ Boy Power foi analisada. A análise apresentada foca na classificação do público de acordo com o tipo de performance que expressa, a partir da análise do conteúdo dos comentários, e apresentamos os resultados qualitativos. Aqui nos alinhamos a Dayan (2006), que vê na performance, ou seja, na dimensão cênica da apresentação de si, uma característica central dos públicos, que é sempre visível.

O primeiro passo foi realizar uma leitura flutuante (BARDIN, 2011) de como a audiência performa em texto o "ser público". Primeiramente, duas posições antagônicas se sobressaltaram, a de Adoradores e Haters. A partir de uma segunda análise cuidadosa dos textos, apreendemos as perfomances de Autodivulgadores, Críticos e Opinativos, e a primeira hipótese formulada: de que as posições são fluídas e muitas vezes paradoxais, partindo de um mesmo sujeito. Conforme avançamos no processo de análise, levando em conta não apenas o conteúdo do comentário em si, mas o contexto apresentado (se era um comentário primeiro, se veio como resposta inicial a um comentário de terceiro, se estava numa thread com múltiplos comentaristas), as outras performances tornaram-se mais claras, foram contabilizadas e analisadas em relação aos temas e supertemas (CORUJA, 2017, p. 123-207).

O que apresentamos a seguir são as categorias de performance em texto resultantes desse processo analítico-metodológico:

1. Adoradores: comentários elogiosos à youtuber e ao conteúdo de suas postagens. Registro da apreciação, seja em textos mais longos, ou curtos, muitos deles com sinais gráficos específicos, como o "<3", que é a representação de um coração na linguagem usada na internet. Essa performance é comum entre os fãs mais engajados (SANDVOSS, 2013). Alguns Adoradores apresentaram outras quatro performances combinadas:

a. Carentes: tentam, com o comentário, ganhar alguma atenção especial da youtuber, numa busca até mesmo de capital social entre o grupo 
de adoradores. Os comentários são sempre pessoais, deixam claro que aguardam ansiosamente algum tipo de atenção especial.

b. Pauteiros: são comentários endereçados à youtuber com perguntas referentes aos temas do vídeo apresentado, apontando sugestões para complementar o que já foi proposto e, principalmente, com sugestões de novos temas.

c. Defensores: costumam enfrentar e responder eventuais haters ou críticos (dois posicionamentos que veremos a seguir). São comentários em defesa tanto da youtuber, quanto das temáticas que ela aborda nos vídeos.

d. Identificados: são relatos reflexivos sobre os temas abordados. Nele há sempre o registro da identificação com o tema que, muitas vezes, vem acompanhado de testemunhos escritos da própria experiência sobre o mesmo assunto.

2. Autodivulgadores: são comentários com o fim de divulgar o próprio canal em um canal de grande visibilidade. O YouTube é uma rede unidirecional, ou seja, não possui um elo duplo, basta que alguém se inscreva para receber as informações, sem a necessidade da outra pessoa fazer o mesmo. A autodivulgação em canais de grande visibilidade é comum porque traz um retorno em termos de novos inscritos. Alguns desses, entretanto, também se posicionam como Adoradores.

3. Ponderados: são performances da parcela do público que responde a questões direcionadas à comunidade de comentaristas do canal, ou respostas àqueles que direcionaram dúvidas. Podem conter pedidos diretos ("Alguém pode me explicar", "Alguém sabe" são alguns começos comuns de comentários ponderados). A resposta, em geral, é cordial e vem de um ou mais comentaristas do canal, que podem também se posicionar como adoradores da youtuber.

4. Opinativos: comentário a partir do qual se registra uma opinião sobre o assunto em questão. Podem concordar ou discordar, complementar 
as informações apresentadas nos vídeos. Em alguns casos, quando não gostam da resposta que recebem de algum outro comentarista (defensor ou ponderado), podem mudar o tom e se posicionar como críticos.

5. Críticos: chegam na caixa de comentários para deixar claro que são contrários ao que está sendo dito nos vídeos, ou que não gostam da youtuber. Diferente dos haters, a performance dos críticos é identificada por comentários mais longos, em que há uma tentativa de desenvolver um argumento justiçando sua contrariedade. Alguns entram nas discussões como críticos, mas ao receber uma resposta mais cordial, mudam o tom e passam a ser, também, ponderados. Outros, ao contrário, ao serem rebatidos de forma mais dura por algum defensor, deixam qualquer traço de cordialidade de lado e passam a performar como haters.

6. Haters: usam normalmente xingamentos em seus comentários. Se são respondidos por Defensores, e tendem a retornar para continuar com os xingamentos e expressões de baixo calão. Ao contrário de alguns canais e relatos de estudos (LANGE, 2007), são minoria na caixa de comentários de Jout Jout.

Com base nessa classificação, é possível ver que Adoradores e Haters são performances opostas na caixa de comentários. Porém todas as outras são dinâmicas, criando fluxos de performances imprevistas, e podem se alterar dependendo do tema do vídeo e do tom do diálogo entre os sujeitos. Notamos, por exemplo, que em algumas situações aqueles que começaram se mostrando como Defensores, ao serem respondidos ou questionados, começavam a responder como Ponderados, mudando o tom do diálogo. O mesmo aconteceu em algumas performances de Críticos, que depois de serem interpelados por Ponderados, mudaram o perfil para Opinativos, tentando desenvolver uma argumentação própria, mesmo que contrária às ideias da youtuber.

Para Marques (2010), esses comentários nem sempre estão apoiados em argumentos logicamente válidos, ou com opiniões de alguma forma justificada. 
É importante salientar que também existem áreas de intersecção: assim, algumas performances de Ponderados podem ou não ser Adoradores e/ou podem (ou não) ser Opinativos. A Figura 1 (a seguir) representa essas categorias, com possíveis mobilidades e intersecções destacadas.

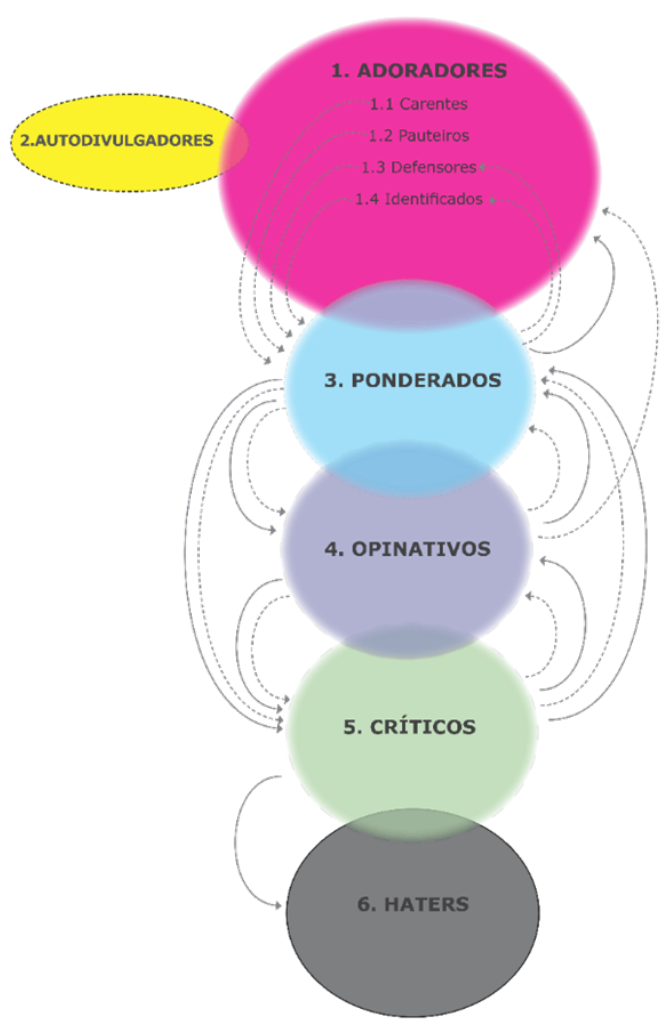

Figura 1. Performances do público na caixa de comentários do canal JoutJout Prazer. Fonte: elaborado pela autora.

A figura representa as dinâmicas que encontramos a partir das performances dos comentários. As setas representam esses fluxos entre o comentário inicial e os subsequentes: dependendo de como começa a interação com outros sujeitos do público, a performance vai se transformando. Haters possuem a posição mais inflexível, os únicos que em nenhum momento transitaram em outras performances após uma interpelação. E mesmo os que não iniciam a interação nesse polo e inicialmente comentaram como Críticos, ao mudar a performance para Haters, tornam-se estáticos nessa posição, não fluindo mais. O outro polo do diagrama, 
os Adoradores, é um pouco menos fixo e mostra uma alteração de performance possível, para Ponderados. Com mais ou menos intensidade, as demais posições todas se alteram, muitas vezes numa mesma thread.

A pesquisa exploratória identificou o feminismo como um supertema do público, mostrando que se faz presente mesmo quando não é citado no conteúdo do vídeo e passa a ser compartilhado (debatido/interpretado/disputado) entre os sujeitos que compõem o público do canal. Contudo, o aspecto dessa pesquisa maior que buscamos trabalhar com mais atenção no espaço desse artigo, é que justamente ao performar sua opinião em texto nas caixas de comentários do YouTube que a audiência se torna público, o que pode acontecer de diferentes modos, com uma fluidez imprevista.

\section{Considerações finais}

No presente artigo trilhamos um caminho teórico para pensar as audiências a partir de canais no YouTube. Contextualizar o tempo atual, a partir da lente da convergência, foi importante para compreender em qual contexto cultural (e histórico) estão inseridos. E esse resgate de como diferentes saberes dentro da Comunicação pensam a audiência, é fundamental para sabermos sobre quem se fala.

Essa discussão foi importante para centrarmos o olhar nos sujeitos que se expõem e tiram parte do seu tempo para comentar em vídeos no YouTube, responder a outros sujeitos, se abrindo (ou não) a um diálogo possível através de um site de rede social. Pensar seus atos, práticas, modos de interação, temas, supertemas a partir do conceito de público contribui por falar das especificidades desses sujeitos. E aqui a performance é a chave de leitura fundamental para esse entendimento. Identificar as performances do público em relação ao conteúdo no YouTube, o que constatamos na análise de um canal específico, mas que pode ser observado em outros tipos de vlog, amplia o entendimento sobre as práticas e relações sociais que acontecem em determinados sites de rede social. 
Essa performance tem características próprias (DAYAN, 2006) e apresenta três dimensões, a cênica, a do sujeito coletivo, e a do compromisso. Essa dimensão performática da audiência, que é justamente o que a transforma em público, dialoga com o resgate teórico do conceito de performance proposto por Amaral, Soares e Polivanov (2018), já que propõem o uso metodológico da performance para analisar produtos e fenômenos comunicacionais.

Outra questão que procuramos deixar claro é de que essas performances do público em caixas de comentários no YouTube não são fixas, podem se alterar sempre em que há uma resposta ou outro contato, seja com a youtuber, seja com outros sujeitos do público. Algumas dessas performances evidenciam que há uma predisposição ao diálogo, dependendo do modo como são interpelados por outros. Assim, mais do que fechar uma questão, queremos com essa pesquisa ampliar o escopo da discussão sobre públicos, principalmente por meio das performances. Aqui temos não apenas um operador metodológico, mas uma chave de leitura importante para muitos fenômenos da contemporaneidade.

\section{Referências}

AMARAL, A.; SOARES, T.; POLIVANOV, B. Disputas sobre performance nos estudos de Comunicação: desafios teóricos, derivas metodológicas. Intercom: Revista Brasileira de Ciências da Comunicação, v. 41, n. 1, 2018.

BABO, I. O acontecimento e seus públicos. Comunicação \& Sociedade, v. 23, 2013.

BARDIN, L. Análise de conteúdo. 4a ed. Lisboa: Edições 70, 2011.

CORUJA, P. Expressões do(s) feminismo(s): discussões do público com a youtuber Jout Jout. Dissertação (Mestrado). Programa de Pós-Graduação em Comunicação e Informação, Universidade Federal do Rio Grande do Sul, 2017. 
CORUJA, P. Comentários no YouTube: uma proposta metodológica de análise a partir de uma pesquisa realizada no canal Jout Jout Prazer. In: MORALES, Y.; SOUSA, L. ; LAPA, B. (orgs.). Experiências metodológicas em pesquisas da comunicação. São Luís: EDUFMA, 2018.

DAYAN, D. Dar atenção à atenção: um olhar sobre as audiências e os públicos. In: ABRANTES, J.; DAYAN, D. (org.). Televisão: das audiências aos públicos. Lisboa: Livros Horizonte, 2006.

DAYAN, D. Televisão, o quase-público. In: ABRANTES, J.; DAYAN, D. (org.). Televisão: das audiências aos públicos. Lisboa: Livros Horizonte, 2006.

DIJCK, J. V. The Culture of connectivity: a critical history of social media. New York: Oxford University Press, 2013.

HINE, C. Estratégias para etnografia da internet em estudos de mídia. In: CAMPANELLA, B.; BARROS, C. Etnografia e consumo midiático: novas tendências e desafios metodológicos. Rio de Janeiro: E-papers, 2016.

HINE, C. Etnografia virtual. Barcelona: UOC, 2004.

JENKINS, H. Cultura da conexão: criando valor e significado por meio da mídia propagável. São Paulo: Aleph, 2014.

JENKINS, H. Cultura da convergência. São Paulo: Aleph, 2009.

JENSEN, K. Media convergence: the three degrees of network, mass and interpersonal communication. New York: Routledge, 2010. 
LANGE, P. Commenting on comments: investigating responses to antagonism on YouTube. Society for Applied Anthropology Conference, Florida (EUA), 2007.

LEMOS, A. Cibercultura. Porto Alegre: Sulina, 2002.

LIVINGSTONE, S. On the relation between audiences and publics. In: LIVINGSTONE, S. Audiences and publics: when cultural engagement matters for the public sphere. Bristol: Intelect Books, 2005.

MARQUES, A. C. S. A conversação informal na internet: condições interacionais e contribuições para uma análise qualitativa. In: BRAGA, J. L.; LOPES, M. I. V.; MARTINO, L. C. (org.). Pesquisa empírica em comunicação. São Paulo: Paulus, 2010.

OROZCO GOMÉZ, G.; JACKSON, D. Súper temas noticiosos en la televisión mexicana. Análisis de la informacción em los noticiários 24 horas y Hechos. Comunicación y Sociedad, n. 37, jan.-jun., 2000.

OROZCO GOMÉZ, G. La televisión, lo televisivo y sus audiências: el estalido de sus vínculos con la ficción. Revista Telos (Cuardernos de Comunicación e innovación), n. 99, out. 2014.

Audiencias conectadas y desconectadas. Dos modos de estar frente a la pantalla televisiva y buscar la interlocución. In: OROZCO GÓMEZ, G. (org.). TVmorfosis: la televisión aberta hacia la sociedad de redes. Cidade do México: Productora de Contenidos Culturales Sagahón Repoll, 2012a.

Desafios educativos em tempos de auto-comunicación massiva: la interlocución de las audiências. Comunicar, n. 38, v. 19, 2012 b. 
Audiencias y pantallas. Lo nuevo, lo viejo y lo que viene. Revista La Mirada de Telemo. Pontifícia Universidad Católica del Perú, n. 1, 2012c.

. Entre pantallas: nuevos escenarios y roles comunicativos entre sus audiencias. In: AGUILAR, M.; NIVON, PORTAL, WINOCUR (coord.). Pensar lo contemporâneo de la cultura situada a la convergência tecnológica. México: UAM/ Anthropos, 2009.

. Audiencias y pantallas en América. Comunicar, n. 30, v. 15, 2008.

. Televisión, audiencias y educación. Buenos Aires: Norma, 2001.

. Hacia una pedagogia de la televidencia. Comunicación y Sociedad, n. 32, jan.-abr., 1998.

. Mas-mediación y audiencia-ción: macrotendências en las sociedades latino-americanas de fin de milenio. Revista Comunicación, n. 100, 1997.

. La investigación en comunicación desde la perspectiva cualitativa. Buenos Aires: Universidad Nacional de La Plata, 1996.

. La mediación en juego. Televisión, cultura y audiencias. Comunicación y Sociedad, n. 10-11, set.-abr., 1991.

. Televisión y producción de significados: três ensayos. Serie Cuadernos de Comunicación y Sociedad, Universidad de Guadalajara, n. 2, 1987.

PRIMO, A. Interação mediada por computador: comunicação, cibercultura, cognição. Porto Alegre: Sulina, 2011. 
RECUERO, R. A conversação em rede: comunicação mediada pelo computador e redes sociais na internet. Porto Alegre: Sulina, 2014.

SANDVOSS, C. Quando a estrutura e a agência se encontram: os fãs e o poder. Tradução de Simone do Vale. Revista Ciberlegenda, n. 28, 2013.

STRANGELOVE, M. Watching YouTube: extraordinary videos by ordinary people. Toronto: University of Toronto Press, 2011.

Submetido em: 26 maio 20 | aprovado em: 22 out. 20 